\title{
Implementasi Gabor Wavelet dan Support Vector Machine pada Deteksi Polycystic Ovary (PCO) Berdasarkan Citra Ultrasonografi
}

\author{
Untari Novia Wisesty ${ }^{\# 1}$, Titik Mutiah \#2 \\ School of Computing, Telkom University \\ Bandung, Indonesia \\ 1'untarinw@telkomuniversity.ac.id \\ 2titik.mutiah@gmail.com
}

\begin{abstract}
Infertility is a difficult condition of couples to have children. One of the recommended examination of fertility health is USG (ultrasonography). To check the fertility of women with a uterus ultrasound check for the presence of disease in the uterus that causes infertility, one of which is PCO (Polycystic Ovary), by looking at the number and size of follicles in the ovaries. However, now the determination sonogram of the uterus is still done manually by a specialist doctor Gynecology. This research intends to help medical experts in diagnosing fertility of women based on the existence of PCO (Polycystic Ovary) are computerized, so the diagnosis can be done quickly and accurately. Detection begins with the initial processing of the ultrasound image and process of feature extraction using Gabor Wavelets. Next, to classify the PCO use Support Vector Machine (SVM) method. Kernel function of Support Vector Machine (SVM) which is used as classifier are linear, RBF, Quadratic, Polynomial to data distribution, the value of the parameter $\mathrm{C}$ multiple of 10 from a range of 0 to 300. With these methods, achieving the highest accuracy using Gabor Wavelet parameters and the best SVM kernel is polynomial, $\mathrm{C}=160,17 \mathrm{x} 17$ mask, frequency $2,3,4,5 \mathrm{~Hz}$ and orientation angle $[\pi / 6 ; \pi / 6 ; \pi]$ have the highest accuracy reach $78.4661 \%$ on testing and $75.5480 \%$ on training, based on each follicle.
\end{abstract}

Keywords: SVM, Gabor Wavelet, image processing, ultrasound of uterus, PCO.

Abstrak
Ketidaksuburan adalah kondisi pasangan suami istri yang sulit untuk memiliki keturunan. Salah satu pemeriksaan kesuburan yang dianjurkan di bidang kesehatan adalah USG (Ultrasonografi). Untuk memeriksa kesuburan wanita dilakukan USG rahim dengan memeriksa keberadaan penyakit di rahim yang menyebabkan kemandulan, salah satunya adalah PCO (Polycystic Ovary), dengan melihat jumlah dan ukuran folikel dalam ovarium. Namun, sampai saat ini penentuan hasil USG rahim masih dilakukan secara manual oleh Dokter Spesialis Kandungan. Penelitian ini bermaksud untuk membantu ahli medis dalam mendiagnosa kesuburan wanita berdasarkan keberadaan PCO secara terkomputerisasi, sehingga hasil diagnosa dapat dilakukan dengan cepat dan akurat. Proses pendeteksian diawali dengan pemrosesan awal pada citra USG dan ekstraksi ciri menggunakan Gabor Wavelet. Selanjutnya, pada tahap klasifikasi PCO digunakan metode Support Vector Machine (SVM). Kernel SVM yang digunakan sebagai classifier adalah fungsi kernel Linear, RBF, Kuadratik, dan Polinomial sesuai dengan kebutuhan persebaran data, dengan nilai parameter $\mathrm{C}$ kelipatan 10 dari rentang 0 hingga 300. Dengan menggunakan metode-metode tersebut, pencapaian akurasi tertinggi didapatkan dengan menggunakan parameter Gabor Wavelet dan SVM yang terbaik 
UNTARI NOVIA WiSESTY ET.AL.

Implementasi Gabor WaVElet dan Support Vector...

yaitu kernel polynomial, $\mathrm{C}=160$, mask $17 \mathrm{x} 17$, frekuensi $2,3,4,5 \mathrm{~Hz}$ dan sudut orientasi $[\pi / 6 ; \pi / 6$; $\pi]$ dengan akurasi uji $78.4661 \%$ dan akurasi latih $75.5480 \%$ berdasarkan pengujian per-folikel.

Kata Kunci: SVM, Gabor Wavelet, pengolahan citra, ultrasonografi rahim, PCO.

\section{PENDAHULUAN}

$\mathbf{P}$

ERKEMBANGAN teknlogi Computer Vision dalam dunia IT sedang marak dan berkembang pesat. Computer Vision sedang marak dikembangkan dalam pembuatan aplikasi bioinformatika. Computer Vison adalah ilmu pengetahuan yang mempelajari bagaimana komputer dapat mengenali objek yang diamati. Dalam kata yang sederhana, Computer Vision ingin membangun mesin pandai yang dapat mengambil suatu keputusan. Penelitian dengan Computer Vision pada bidang medis sudah banyak diterapkan, khususnya pada pendeteksian PCO (Polycystic Ovary). PCO adalah folikel yang berkembang membesar dan terhenti pada ukuran 5-7 mm, serta tak kunjung matang akan terus menerus menghasilkan hormon estrogen yang mana bertanggung jawab mempengaruhi pertumbuhan selaput lendir pada rongga rahim. Pemeriksaan PCO dengan ultrasonografi adalah salah satu cara untuk mengetahui apakah pasien menderita PCO atau tidak dengan melihat jumlah dan ukuran folikel dalam ovarium. Namun, sampai saat ini penentuan hasil USG rahim masih dilakukan secara manual dengan visual manusia. Hal ini memakan waktu yang lama karena harus dilakukan diagnosa terlebih dahulu dari hasil USG tersebut dan menghasilkan diagnosa yang tidak konsisten antar ahli USG karena keterbatasan visual manusia $[1,2]$.

Melihat permasalahan tersebut, penelitian terhadap pendeteksian PCO sudah banyak dilakukan dengan kekurangan dan kelebihan tertentu. Hal ini disebabkan karena citra ultrasonografi yang mempunyai banyak noise dalam mendapatkan citra folikel PCO yang berkualitas baik. Selain itu folikel PCO memiliki bentuk dan ukuran yang bervariasi, sehingga untuk mengembangkan komputasi dan performansi yang ideal untuk pengenalan folikel PCO adalah hal yang sulit. Pada penelitian sebelumnya, deteksi folikel dilakukan dengan pendekatan region growing dan steorology [2]. Pendekatan region growing untuk melakukan segementasi citra dengan dimulai dari beberapa piksel (seeds) yang merepresentasikan daerah citra yang berbeda dan tumbuh berkembang sehingga membentuk wilayah yang lebih lebar pada Citra USG. Sedangkan pendekatan stereologi digunakan dalam penghitungan jumlah folikel. Berdasarkan penelitian yang telah dilakukan tersebut, sistem masih sulit mendeteksi folikel yang berukuran kecil, yang juga biasanya memiliki tingkat kecerahan yang cerah atau yang sulit dipahami oleh mata telanjang. Selain itu, sistem masih kesulitan dalam membedakan beberapa folikel yang berdekatan pada latar belakang yang sangat gelap. Dari permasalahan pada penelitian sebelumnya, penulis menggunakan pendekatan metode Gabor Wavelet pada saat pengambilan ciri dan metode Support Vector Machine (SVM) pada saat melakukan klasifikasi.

Hal yang mendasari dalam pengambilan metode Gabor Wavelet adalah karena Gabor Wavelet memiliki kelebihan menangkap lokal struktur sesuai dengan frekuensi spasial (skala), lokalisasi spasial, dan orientasi selektivitas, mereka banyak diterapkan di banyak daerah penelitian, seperti tekstur analisis dan citra segmentasi yang kompeten dan berhasil dalam segmentasi tumor [3]. Selain itu, Gabor Wavelet dikenal menjadi salah satu yang paling efektif dan umum digunakan dalam pendekatan ekstraksi ciri, karena kemampuannya untuk menghasilkan informasi resolusi beragam yang dioptimalkan dalam waktu dan domain frekuensi, yang sangat penting dalam segmentasi Magnetic Resonance Imaging (MRI) [4, 5]. Dengan kata lain, Gabor Wavelet pada saat proses ekstraksi ciri yang memiliki kemampuan menyediakan informasi resolusi tinggi tentang orientasi dan isi frekuensi spasial dari struktur gambar [6]. Pada proses klasifikasi, SVM dipilih karena berusaha menemukan hyperplane yang terbaik pada input space. Prinsip dasar SVM adalah linear classifier, dan selanjutnya dikembangkan agar dapat bekerja pada problem non-linear dengan memasukkan konsep kernel 
trick pada ruang kerja berdimensi tinggi [7]. Selain itu, Support Vector Machine (SVM) merupakan supervised learning yang hanya perlu melakukan satu kali training dan merupakan solusi global optimal [15].

Dengan demikian, kombinasi antara Gabor Wavelet dan SVM dapat digunakan untuk membangun sebuah sistem pendeteksi PCO pada citra ultrasonografi yang dapat mengidentifikasi dari sisi sudut, frekuensi dan tekstur dari folikel PCO. Gabor Wavelet berfungsi untuk mengekstraksi ciri folikel PCO yang kaya akan informasi. Selanjutnya, SVM akan melakukan proses klasifikasi yang optimal dalam mengidentifikasi folikel PCO. Sistem ini akan diterapkan dan dianalisis melalui proses pengujian dan simulasi. Simulasi dilakukan dengan mengklasifikasikan citra ultrasonografi rahim berdasarkan hasil ekstraksi ciri ke dalam dua kelas yaitu PCO dan non-PCO.

\section{PENELUSURAN PUSTAKA}

PCO adalah suatu keadaan di mana satu indung telur mengandung 10 folikel atau lebih yang dapat dilihat dari ultrasound scan, tetapi tidak mengalami tanda-tanda atau gejala yang membentuk syndrome. PCOS adalah gangguan pada sistem endokrin yang terjadi pada wanita pada masa reproduksi, akibat adanya hormon yang memicu hormon lain sehingga terjadi gangguan keseimbangan hormonal, gangguan ini disertai ditemukan adanya folikel yang berjumlah 10 atau lebih. Gejala yang dialami penderita PCOS diantaranya adalah ketombe, jerawat, nyeri pinggul, diabetes tipe 2, dan siklus haid tidak teratur. Sistem endokrin adalah sekumpulan kelenjar dan organ yang memproduksi dan mengatur hormon dalam aliran darah untuk mengontrol banyak fungsi tubuh [8]. Sebelum masuk kedalam proses utama, dilakukan preprocessing, dimana merupakan proses pengolahan data asli sebelum data tersebut diolah. Dalam hal ini, tujuan preprocessing yang dilakukan antara lain: mengubah citra $R G B$ menjadi gray-scale, ekualisasi histogram, binerisasi citra, dilasi dan erosi, eliminasi obyek yang tidak penting, croping citra, resize citra, edge detection/edge enhancement, dan segmentasi folikel.

Gabor Wavelet merupakan pengembangan dari transformasi Wavelet yang memiliki tujuan yang sama yaitu memunculkan ciri-ciri khusus dari gambar yang telah dikonvolusi terhadap kernel. Gabor Wavelet sangat relevan dengan biological dan teknikal properties. Gabor Wavelet akan melawan brightness yang berbeda-beda pada gambar. Lokasi yang terbatas dalam space dan frekuensi menghasilkan sejumlah kekuatan tertentu untuk melawan translasi, distorsi, rotasi dan scalling. Gabor Wavelet handal dalam mengatasi rotasi dan noise.

Rumus Gabor dapat dilihat sebagai berikut [1]:

dimana:

$$
g(x, y)=\frac{1}{2 \pi} \exp \left[-\alpha^{2} \frac{x^{2}+y^{2}}{2}\right] \exp \left[j \pi \alpha^{j}(x \operatorname{Cos} \theta+y \operatorname{Sin} \theta)\right]
$$

$$
\begin{array}{ll}
j & =\text { frekuensi }=0,1,2, \ldots \\
\theta & =\text { orientasi atau sudut pandang terhadap image berkisar dari } 0 \text { hingga } 2 \pi \\
\alpha & =1 / \sqrt{2}
\end{array}
$$

Proses filtering image menggunakan Gabor Wavelet dipandang sebagai operasi konvolusi antara matrik image dengan matrik kernel konvolusi. Parameter-parameter seperti $x, y, j$, dan $\theta$ digunakan untuk menentukan kernel konvolusi disisi real dan imajiner. Kernel konvolusi di sisi real dan imajiner inilah yang merupakan filter Gabor disisi real dan imajiner. Operasi konvolusi antara matrik image dengan kernel konvolusi imajiner akan menghasilkan matrik image imajiner (im), sedangkan operasi konvolusi antara matrik image dengan kernel konvolusi real akan menghasilkan matrik image real (re). Kedua matrik tersebut memiliki dimensi yang sama seperti matrik image. Matrik image imajiner dan matrik image real kemudian di-magnitude-kan untuk mendapatkan matrik yang berisi nilai absolut dari image.

Ciri yang diekstrak pada penelitian ini merupakan ciri tekstur yang diantaranya adalah entropi, ciri mean, ciri energi, dan gabungan dari ketiganya. Ciri diekstrak dari matrik absolut. Ciri entropi, mean, energi, dan gabungan tersebut merupakan satu nilai yang didapat dari kombinasi satu nilai sudut orientasi $\theta$ dan satu nilai frekuensi j. Kombinasi nilai $\theta$ dan j yang berbeda akan menghasilkan nilai ciri yang berbeda pula. Nilai-nilai ciri ini merupakan elemen-elemen pada satu vektor ciri image. Dimensi vektor ciri yang dihasilkan tergantung pada jumlah kombinasi $\theta$ dan $\mathrm{j}$ yang digunakan.

Berikut parameter cirinya [8]: 
UNTARI NOVIA WiSESTY ET.AL.

Implementasi Gabor WaVElet dan Support Vector...

1. Mean $(\mu)$, menunjukkan ukuran dispersi dari suatu citra.

$$
\mu=\sum n f_{n} \cdot p\left(f_{n}\right)
$$

2. Variance $\left(\sigma^{2}\right)$, menunjukkan variasi elemen pada histogram dari suatu citra.

$$
\sigma^{2}=\frac{1}{n-1} \sum_{i=1}^{n}\left(f_{n}-\mu\right)^{2}
$$

3. Skewness $\left(\alpha_{3}\right)$, menunjukkan tingkat kemiringan relatif kurva histogram dari suatu citra.

$$
\alpha_{3}=\sum_{n} \frac{E\left(p\left(f_{n}\right)-\mu\right)^{3}}{\sigma_{3}}
$$

4. Kurtosis $\left(\alpha_{4}\right)$, menunjukkan tingkat keruncingan relatif kurva histogram dari suatu citra.

$$
\alpha_{4}=\sum_{n} \frac{E\left(p\left(f_{n}\right)-\mu\right)^{4}}{\sigma_{4}}
$$

5. Entropy $(H)$, menunjukkan ukuran ketidakaturan bentuk dari suatu citra.

dimana:

$$
H=-\sum n p\left(f_{n}\right) \cdot \log _{2} \cdot p\left(f_{n}\right)
$$

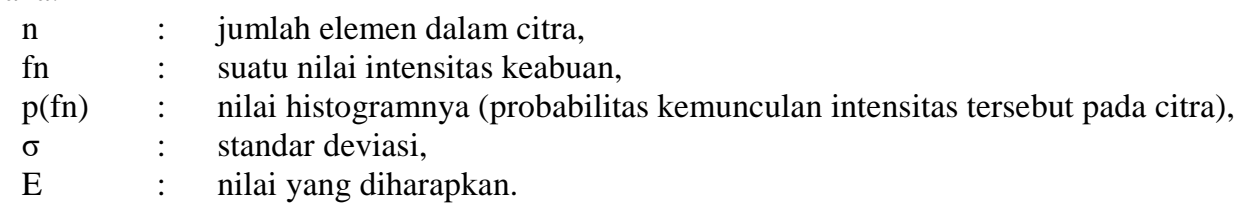

Metode klasifikasi yang digunakan dalam penelitian ini adalah Support Vector Machine (SVM). SVM merupakan salah satu teknik yang masuk ke dalam kelas supervised sehingga dalam pengimplementasiannya membutuhkan kelas target. SVM ini dapat menemukan solusi yang global optimal, yaitu SVM selalu mencapai solusi yang sama untuk setiap kali dilakukan learning [8]. Tujuan dalam SVM ini adalah berusaha untuk menemukan hyperplane atau fungsi pemisah (klasifier) yang optimal yang dapat memisahkan dua set data dari dua kelas yang berbeda, dengan menggunakan ruang hipotesis berupa fungsi-fungsi linier dalam sebuah ruang fitur (feature space) berdimenasi tinggi, dimana dilatih dengan algoritma pembelajaran yang didasarkan pada teori optimasi dengan mengimplementastikan learning bias yang berasal dari teori pembelajaran statistic [8].

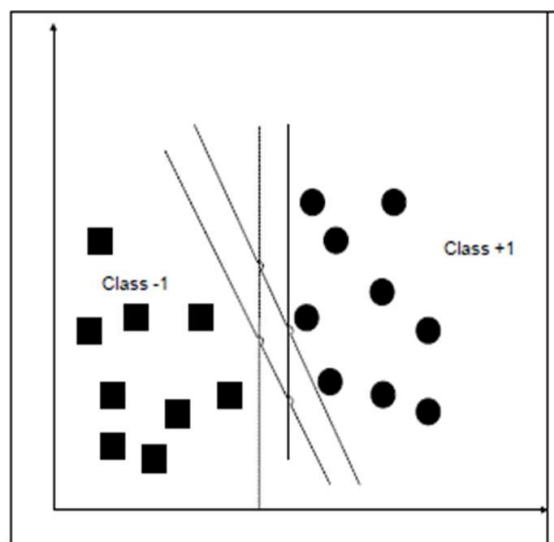

(a)

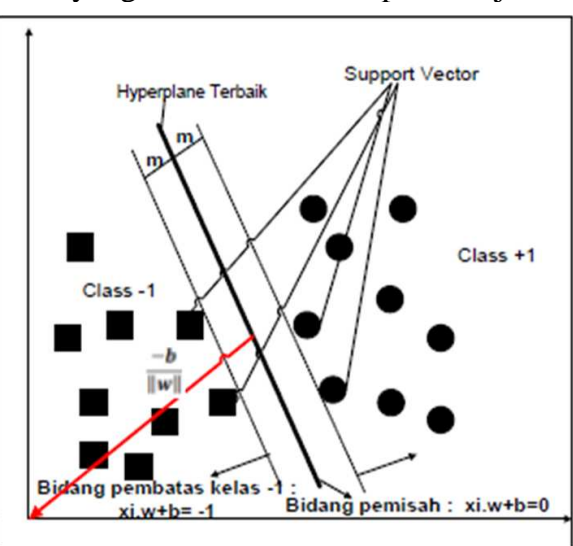

(b)

Gambar 1. (a) Alternatif Hyperplane (b) Hyperplane Terbaik dengan Margin Terbesar [8]

\section{PEMODELAN DAN DESAIN SISTEM}

Perancangan sistem pada perangkat lunak yang akan dibangun bertujuan untuk menghasilkan keluaran (output) berupa klasifikasi folikel PCO atau folikel normal berdasarkan citra ultrasonografi. Hasil testing akhir menyatakan jika jumlah folikel yang terdeteksi PCO lebih dari sama dengan 10 maka hasil output adalah menderita PCOS, sedangkan jika kurang dari 10 maka hasil output normal. Pembangunan sistem ini menggunakan dua metode yaitu proses ekstraksi ciri dengan menggunakan metode Gabor Wavelet dan proses klasifikasi menggunakan metode Support Vector Machine (SVM). Sistem yang dirancang merupakan sistem 
yang dapat melakukan identifikasi folikel yang termasuk PCO atau tidak. Secara umum tahapan yang akan dilakukan untuk membangun sistem dapat dilihat pada Gambar 2.

Berdasarkan Gambar 2, sistem yang dibangun meliputi fase training dan fase testing. Fase training digunakan untuk membentuk model hyperplane dari metode SVM berdasarkan citra USG yang sebelumnya telah melalui proses preprocessing dan ekstraksi ciri menggunakan metode Gabor Wavelet. Sedangkan fase testing digunakan untuk menguji dan mengukur performansi dari system yang telah dibangun pada fase training.

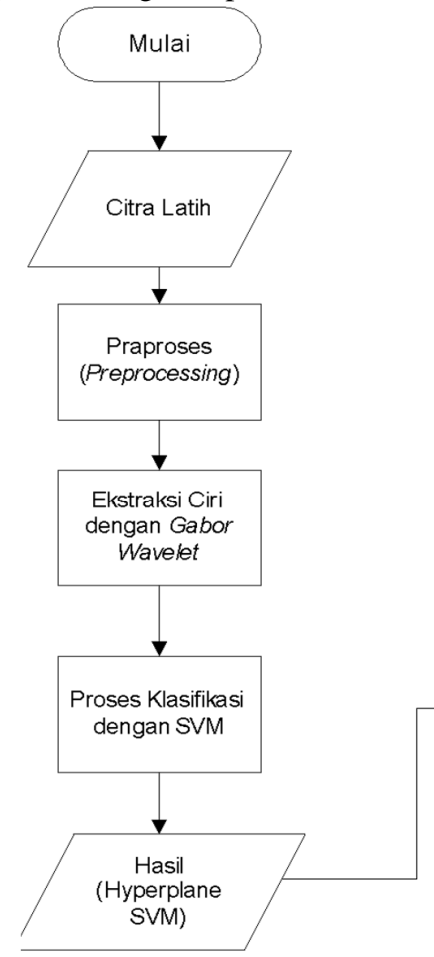

(A)

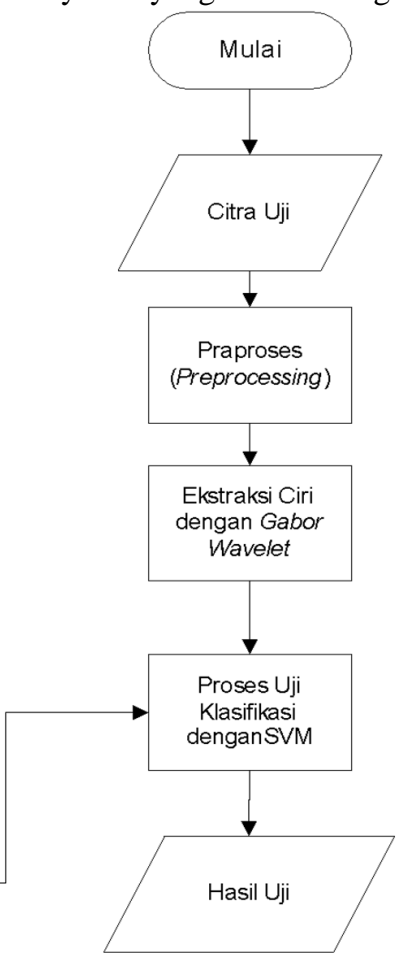

(B)

Gambar 2. Alur Proses Pendektesian dan Klasisfikasi PCO, (A) Diagram Alir Proses Pelatihan, (B) Diagram Alir Proses Pengujian

Data yang digunakan dalam riset ini adalah citra ultrasonografi ovarium yang berbentuk digital dan sudah divalidasi oleh orang yang ahli dalam bidangnya. Pengambilan data dilakukan di mitra Klinik Bersalin Permata Bunda Syariah, Cirebon yang disimpan dalam bentuk citra digital dengan ukuran 760 x 574 piksel. Citra USG rahim yang memiliki kemungkinan terdeteksi PCO divalidasi oleh Dr. Julius T. Pangayoman, SpOG, Ahli Kebidanan dan Penyakit Kandungan Melinda Hospital Bandung. Dimana, pasien yang terdeteksi lebih dari 10 folikel dalam hasil USG rahimnya, diindikasikan menderita PCO.

TABLE I

ILUSTRASI PEMBAGIAN CITRA

\begin{tabular}{|l|l|l|}
\hline & PCO & \multirow{2}{*}{ Normal } \\
\hline \multirow{3}{*}{ Training set } & Citra ke 1 & Citra ke 1 \\
\cline { 2 - 3 } & $\ldots$ & $\ldots$ \\
\cline { 2 - 3 } & Citra ke 70 & Citra ke 11 \\
\hline \multirow{3}{*}{ Testing set } & Citra ke 1 & Citra ke 1 \\
\cline { 2 - 3 } & $\ldots$ & $\ldots$ \\
\cline { 2 - 3 } & Citra ke 34 & Citra ke 6 \\
\hline
\end{tabular}

Penggambaran diagram alir akuisisi citra dapat dilihat pada Gambar 3. 
UNTARI NOVIA WiSESTY ET.AL.

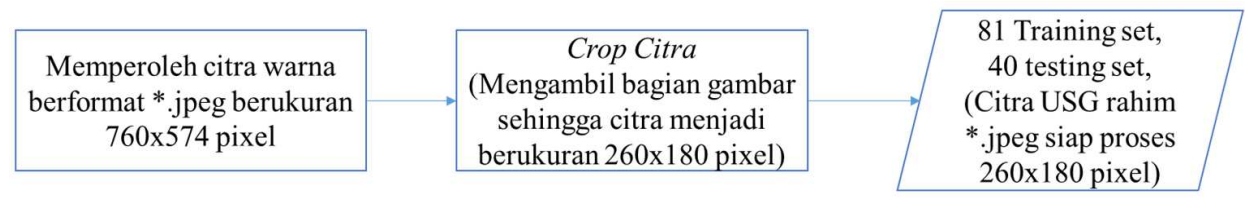

Gambar 3. Alur akuisisi citra

Setelah proses akuisisi citra USG, citra USG yang berupa bagian-bagian penting masuk ke proses preprocessing. Pada tahap ini akan dilakukan beberapa urutan proses yaitu grayscalling, equalization histogram, binerisasi citra, morphology filtering, data cleaning, edge detection, serta segmentasi citra. Berikut adalah penjelasan dari masing-masing proses.

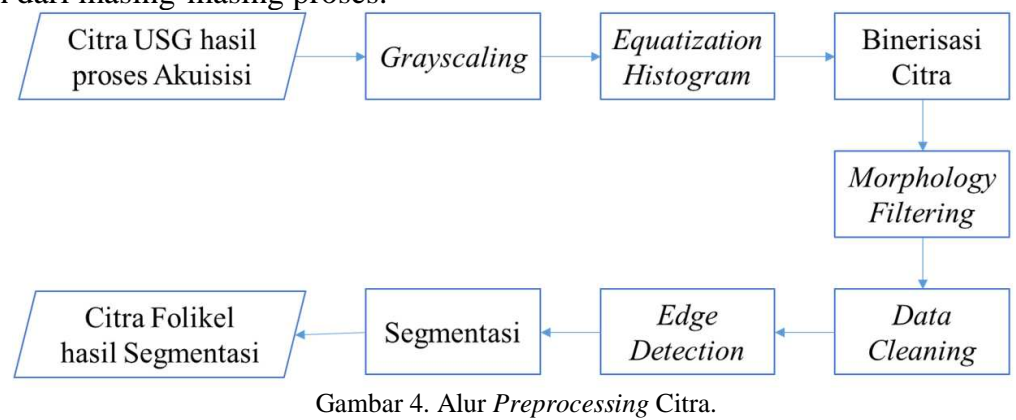

Teknik grayscale digunakan untuk mengawali proses enhancement menjadi matriks dua dimensi agar bisa dilakukan proses preprocessing selanjutnya. Proses grayscalling mengubah image RGB (3 dimensi) menjadi grayscale ( 2 dimensi) atau biasanya disebut mengubah citra berwarna menjadi citra keabu-abuan, menggunakan persamaan berikut.

Dimana:

$$
I(i, j)=\frac{R(i, j)+G(i, j)+B(i, j)}{3}
$$

$I(i, j)=$ nilai intensitas citra grayscale

$\mathrm{R}(\mathrm{i}, \mathrm{j})=$ nilai intensitas warna merah dari citra RGB.

$\mathrm{G}(\mathrm{i}, \mathrm{j})=$ nilai intensitas warna hijau dari citra RGB.

$\mathrm{B}(\mathrm{i}, \mathrm{j})=$ nilai intensitas warna biru dari citra RGB.

Teknik histogram equalization bertujuan untuk menghasilkan suatu citra keluaran yang memiliki nilai histogram yang relatif sama. Teknik ini digunakan untuk menangkap perbedaan beberapa pixel yang memiliki frekuensi yang kecil (lemah), padahal pixel-pixel frekuensi lemah itu mempunyai nilai informasi yang kaya. Dan jika hanya dilihat dengan kasat mata saja biasanya dianggap bahwa pixel-pixel tersebut memiliki warna yang sama.

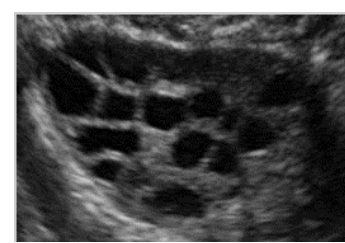

(a)

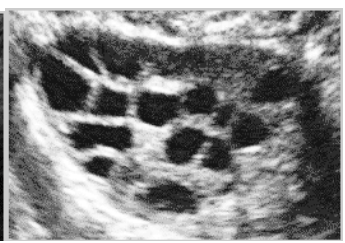

(b)

Gambar 5. (a) Sebelum Ekualisasi Histogram (b) Setelah Ekualisasi Histogram

Pada proses binerisasi citra, citra diubah menjadi hitam putih yang berarti matriks data citra berisi nilai 1 atau 0 , berdasarkan threshold yang telah ditentukan. 


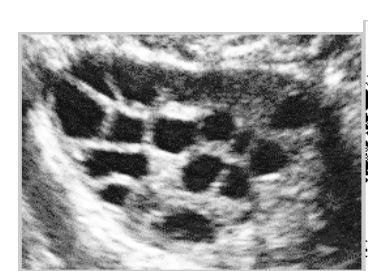

(a)

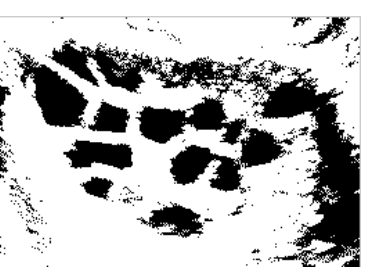

(b)

Gambar 6. (a) Citra sebelum proses binerisasi (b) Citra sebelum proses binerisasi

Morfologi citra yang dilakukan pada makalah ini adalah dilasi dan erosi. Dilasi untuk menipiskan objek agar noise yang terhubung dengan objek lain bisa terpisah. Dan setelah dilakukan penipisan, dilakukan penebalan kembali agar objek yang bagiannya hilang karena penipisan dapat diperbaiki kembali.

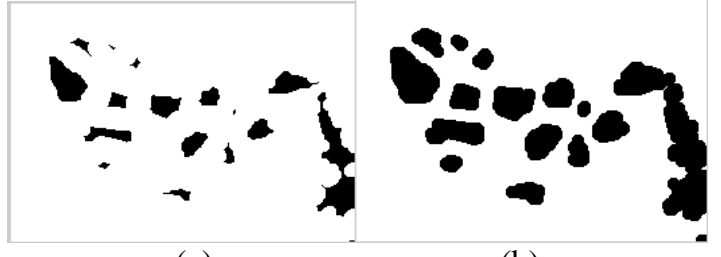

(a)

(b)

Gambar 7. (a) Citra hasil dilasi (b) Citra hasil erosi

Setelah proses morfologi citra, dilakukan invers citra, dimana hitam menjadi putih dan putih menjadi hitam. Proses ini dilakukan karena objek lebih mudah terdeteksi dalam keadaan warna putih dengan background hitam. Pada tahap ini dilakukan pembersihan objek yang tidak penting (data cleaning), yang dilakukan dengan membersihkan objek yang berukuran kecil sekali dan objek yang menempel di border. Untuk memperlihatkan objek-objek folikel yang terdeteksi pada citra asli dilakukan deteksi tepi dengan metode canny. Proses selanjutnya yaitu menentukan bounding box dari folikel yang telah terdeteksi dan melakukan cropping pada citra.

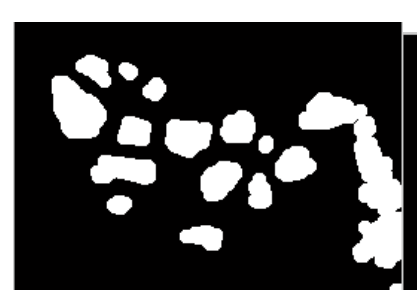

(a)

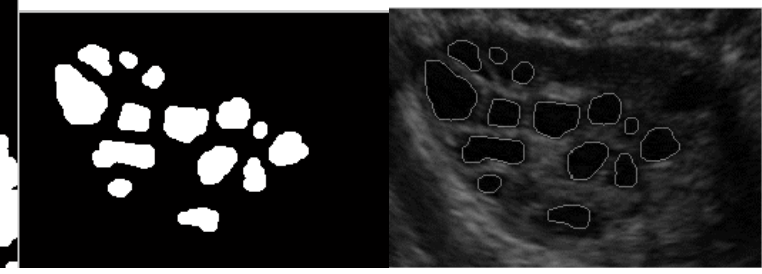

(b) (c)

Gambar 8. (a) Hasil invers citra, (b) Hasil eliminasi objek noise (c) Hasil deteksi tepi

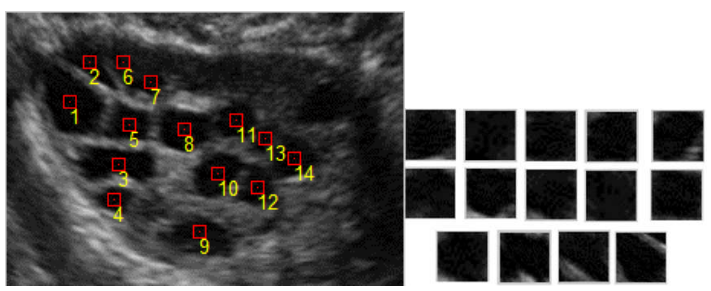

Gambar 9. Segmentasi folikel.

Tahap ekstraksi ciri merupakan proses untuk mendapatkan ciri penting yang terkandung di dalam gambar USG sebelum pengklasifikasian. Berikut diagram alir proses ekstraksi ciri. 
UNTARI NOVIA WiSESTY ET.AL.

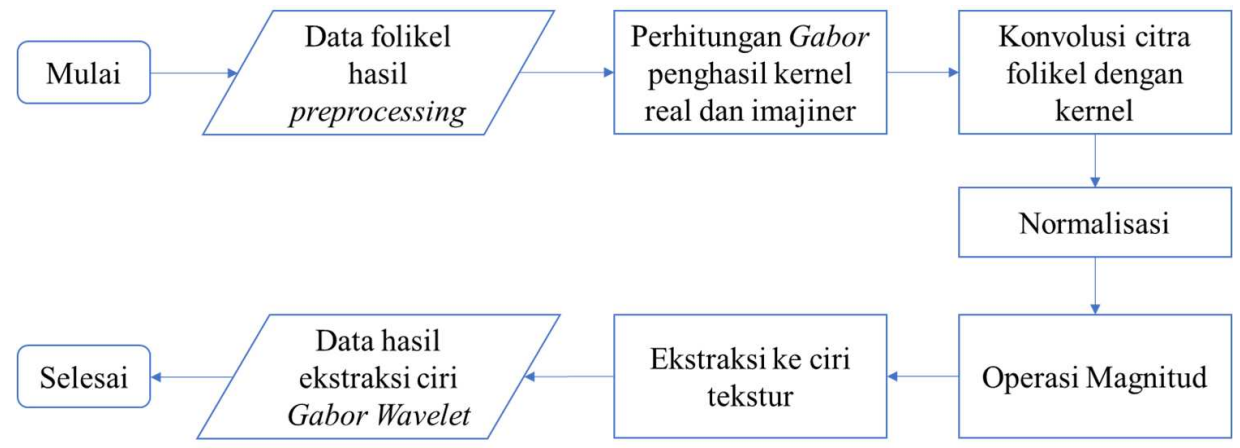

Gambar 10. Alur ekstraksi ciri Gabor Wavelet

Untuk lebih jelasnya, berikut tahap-tahap ekstraksi ciri Gabor Wavelet yang dilakukan:

1. Database citra folikel hasil segmentasi dijadikan sebagai inputan Gabor Wavelet.

2. Melakukan perhitungan pembangkit kernel berdasarkan inputan frekuensi dan sudut orientasi yang menghasilkan kernel real dan imajiner.

3. Operasi konvolusi antara citra inputan dengan kernel real menghasilkan matriks image real (re).

4. Operasi konvolusi antara citra input dengan kernel imajiner menghasilkan matriks image imajiner (im).

5. Setiap elemen matrik image real (re) dan matriks image imajiner (im) dinormalisasi dengan cara membaginya dengan elemen matrik image real (re) dan matriks image imajiner (im).

6. Matriks image real (re) dan matriks image imajiner (im) yang sudah dinormalisasi kemudian di-magnitudekan untuk mendapatkan matrik absolut.

7. Matrik absolut diekstrak untuk diambil cirinya. Keluaran ekstraksi tersebut berupa vektor ciri [9].

8. Vektor ciri diekstrak ke beberapa ciri tekstur, diantaranya adalah ciri Mean, Entropy, Kurtosis, Skewness, dan Variance.

9. Ciri tekstur tersebut kemudian disimpan dalam database dan digunakan sebagai data input proses klasifikasi SVM.

Pada proses klasifikasi dengan SVM, proses terbagi menjadi 2 jenis yang meliputi:

- Proses training: Dalam proses ini diterapkan training set. Untuk menentukan kelas diperlukan latihan pada sistem dengan data training yang telah dibagi sebelumnya. Data training ini membantu sistem dalam mencari hyperline terbaik yaitu hyperline yang terletak di tengah-tengah antara dua set obyek dari dua kelas, dengan memaksimalkan margin antara dua set obyek. Nilai w pada data training akan berubah ke kelas +1 atau -1 hingga benar pengelompokkannya.

- Proses testing: Untuk membuktikan kebenaran pengelompokkan tipe folikel, maka dilakukan pengujian dengan data testing. Sehingga didapatkan hasil klasifikasi dan akan mengeluarkan hasil akurasi proses yang dapat dievaluasi.

Sistem yang telah dibangun akan diukur performansinya berdasarkan waktu running dan akurasi system yang dihitung berdasarkan Confusion Matrix (accuracy, True Positive Rate, dan True Negative Rate). Berikut persamaan yang digunakan untuk menghitung ketiga proses tersebut.

Dimana:

$$
\begin{aligned}
& \text { Accuracy }=\frac{T P+T N}{T P+F P+F N+T N} \\
& \text { True Positive Rate }=\frac{T P}{T P+F N} \\
& \text { True Negative Rate }=\frac{T N}{F P+T N}
\end{aligned}
$$

TP (True Positive): folikel PCO yang benar teridentifikasi sebagai folikel PCO.

FN (False Positive): folikel normal yang salah teridentifikasi sebagai folikel PCO.

TN (True Negative): folikel normal yang benar teridentifikasi sebagai folikel normal.

FN (False Negative): folikel PCO yang salah teridentifikasi sebagai folikel normal 


\section{ANALISIS DAN PENGUJIAN}

\section{A. Pengujian Penggunaan Mask pada Gabor Wavelet}

Pengujian ini bertujuan untuk menganalisa pengaruh penggunaan mask pada proses ekstraksi ciri menggunakan Gabor Wavelet. Nilai mask yang diuji yaitu 35x35, 17x17, dan 9x9.

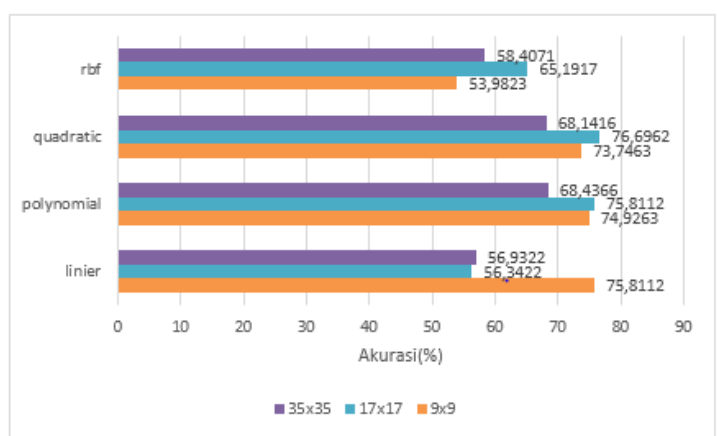

Gambar 11. Hasil percobaan penggunaan mask yang berbeda pada Gabor Wavelet

Berdasarkan hasil pengujian pada Gambar 11, akurasi tertinggi didapat pada kernel quadratic sebesar 76.70\% dengan mask 17x17 piksel. Sedangkan untuk akurasi terendah dimiliki oleh kernel linier dengan akurasi 56.34\% dengan mask 17x17 piksel juga. Berdasarkan hasil pengujian mask tersebut dapat disimpulkan bahwa ukuran mask tidak berbanding lurus dengan besarnya akurasi yang dihasilkan system jika kernel yang digunakan berbeda. Jadi semakin besar ukuran mask, tidak menjadi dasar untuk memperoleh akurasi yang lebih besar juga.

\section{B. Pengujian Parameter Frekuensi dan Orientasi}

Pengujian ini bertujuan untuk menganalisa pengaruh parameter frekuensi dan sudut orientasi pada Gabor Wavelet. Nilai yang digunakan yaitu 3 skala nilai frekuensi dan 8 sudut orientasi, serta 4 skala frekuensi dan 6 sudut orientasi.

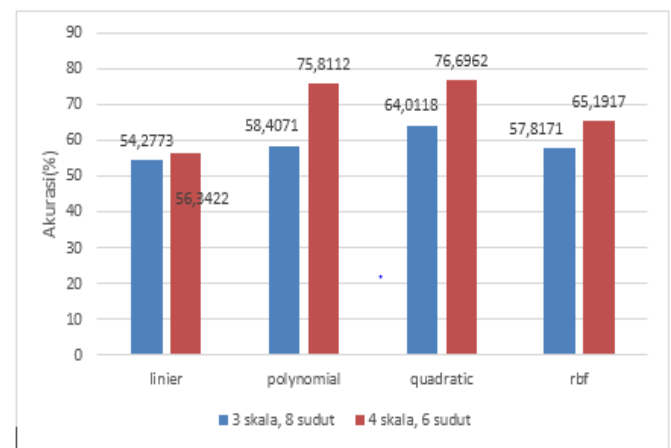

Gambar 12. Hasil pengujian frekuensi dan orientasi berbeda yang menghasilkan 24 ciri

Gambar 12 memperlihatkan akurasi dari jumlah ciri yang sama tapi memiliki frekuensi dan sudut orientasi yang berbeda. Dapat dilihat bahwa ciri dengan 4 skala frekuensi $(2,3,4,5 \mathrm{~Hz})$ dan 6 sudut orientasi $(\pi / 6: \pi / 6$ $: \pi)$ didapatkan akurasi lebih baik daripada 3 skala frekuensi dan 8 sudut orientasi. Dalam model yang terbentuk, dibutuhkan skala yang lebih besar untuk mendapatkan performansi yang lebih baik. Parameter skala performansi dan sudut orientasi tersebut membuat Gabor Wavelet handal dalam mengatasi citra yang terotasi. Ciri yang dihasilkan berupa perkalian dari jumlah frekuensi dan orientasi yang menghasilkan kernel real dan imajiner yang dikonvolusikan dengan citra USG yang telah disegmentasi dan dihitung nilai magnitudnya. 
UNTARI NOVIA WiSESTY ET.AL.

Implementasi Gabor WaVElet dan Support Vector...

\section{Pengujian Jumlah Ciri Vektor Pada Gabor Wavelet}

Pengujian ini bertujuan untuk menganalisa pengaruh dari jumlah ciri yang dihasilkan dari metode Gabor Wavelet. Jumlah ciri yang akan diujikan yaitu 16, 24, dan 32 ciri.

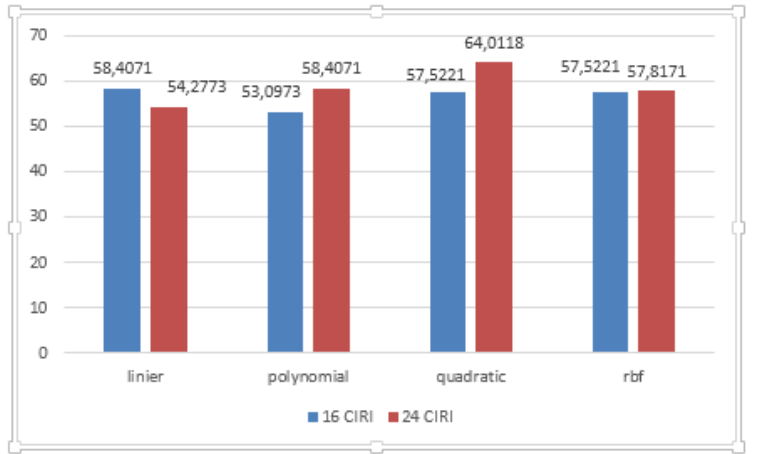

Gambar 13. Hasil perbedaan jumlah ciri vektor Gabor Wavelet

Gambar 13 menunjukkan akurasi dari pengujian ekstraksi ciri yaitu 16 ciri (frekuensi $2 \mathrm{~Hz}, 3 \mathrm{~Hz} \mathrm{dan} 4 \mathrm{~Hz}$, sudut orientasi $[\pi / 8 ; \pi / 8 ; \pi]$ ) dan ekstraksi ciri dengan 24 ciri (frekuensi $2 \mathrm{~Hz}$ dan $3 \mathrm{~Hz}$, sudut orientasi [ $\pi / 8$; $\pi / 8 ; \pi]$ ). Hasil dari pengujian tersebut menunjukkan bahwa dengan 24 ciri pada kernel quadratic mendapatkan akurasi yang terbaik.

\section{Pengujian Penggunaan Ciri Tekstur}

Penentuan penggunaan ciri tekstur atau tidak juga akan berpengaruh pada hasil akurasi klasifikasi SVM, maka untuk mengetahuinya dapat dilihat pada tabel dibawah ini.

TABLE II

AKURASI TERTINGGI DARI PENGUJIAN DENGAN CIRI TEKSTUR DAN TANPA CIRI TEKSTUR

\begin{tabular}{|c|c|c|c|c|}
\hline Ciri Tekstur & Kernel & C & $\begin{array}{c}\text { Akurasi } \\
\text { latih (\%) }\end{array}$ & $\begin{array}{c}\text { Akurasi } \\
\text { uji (\%) }\end{array}$ \\
\hline V & Quadratic & 30 & 74.2097 & 76.6962 \\
\hline X & Polynomial & 160 & 75.5408 & 78.4661 \\
\hline
\end{tabular}

Dari hasil pengujian tabel 2, didapat akurasi tertinggi pada pengujian tanpa menggunakan ciri tekstur dengan akurasi uji 78,4661\%. Ternyata tanpa menggunakan ciri tekstur, sistem memiliki akurasi yang lebih baik dalam mendeteksi folikel PCO. Ini dikarenakan, ciri dari folikel cenderung pada perbedaan sudut orientasinya. Sehingga Gabor Wavelet mendukung dalam pengambilan ciri sudut orientasi tersebut.

\section{E. Pengujian Waktu Komputasi Sistem}




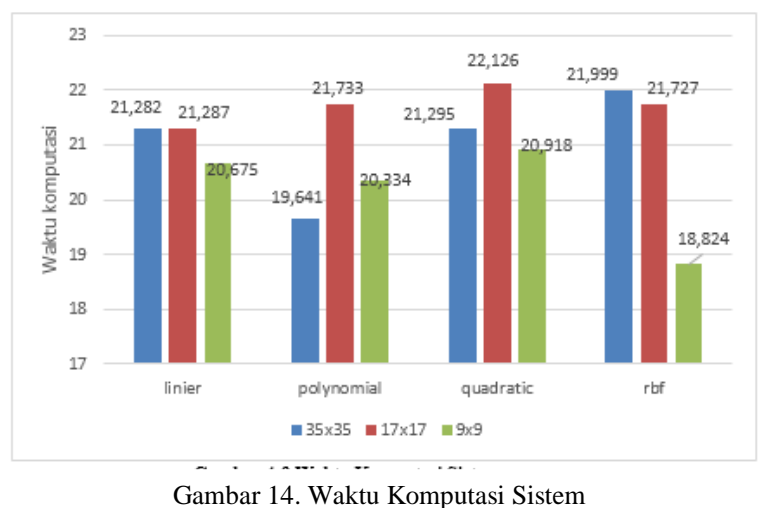

Pada Gambar 14 dapat dilihat bahwa waktu komputasi kernel quadratic dengan mask 9x9 lebih cepat daripada penggunaan kernel lainnya. Untuk keseluruhan mask 9x9 juga mendominasi waktu komputasinya lebih singkat. Hal tersebut dikarenakan semakin kecil ukuran piksel kernel, maka semakin cepat waktu komputasinya, sehingga tidak memakan banyak memori untuk memprosesnya. Seperti halnya ketika memasukkan image yang berukuran besar, maka komputasi untuk memproses image tersebut juga semakin besar.

Untuk mengetahui performansi sistem terhadap keakuratan pendeteksian PCO, dilakukan evaluasi performansi. Dalam evaluasi performansi ini, akan dijelaskan tahapan-tahapan proses training dan testing dengan membandingkan validasi dari dokter, sehingga dapat diketahui perbandingan hasil output dari sistem dengan validasi dari dokter.

\section{A. Training}

Diawali dengan tahap preprocessing didapatkan folikel-folikel dari setiap image data training. Diambil satu sample citra sebagai contoh gambaran proses.

a. Preprocessing

Pertama citra di-crop berdasarkan aturan yang sudah dianalisis ukurannya. Berikut gambar asli dari dokter, validasinya, dan hasil crop.
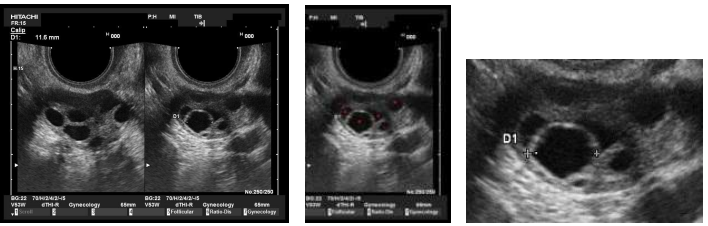

Gambar 15. Citra Asli, Validasi, dan Hasil Crop

Kemudian citra di preprocessing sehingga mendapat hasil deteksi folikel PCO dan dilakukan cropping.

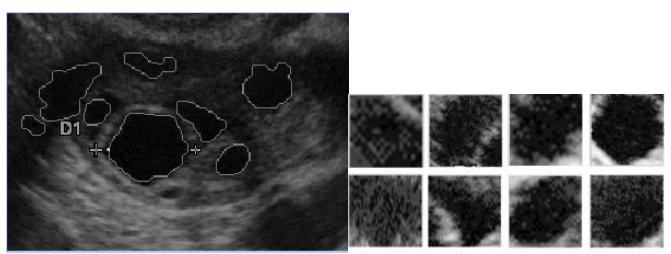

Gambar 16. Citra Hasil Preprocessing

Hasil cropping dari semua citra akan dimasukkan dalam satu database folikel. 
UNTARI NOVIA WiSESTY ET.AL.

b. Ekstraksi Ciri

Folikel-folikel tersebut diekstraksi cirinya menggunakan Gabor Wavelet.

c. Target Dokter dan klasifikasi SVM

Tiap folikel diberikan target output sesuai validasi dari dokter. Kemudian dilakukan proses klasifikasi SVM yaitu mencocokkan cirinya dengan bank folikel training yang sudah diklasifikasikan pada kelas PCO dan non-PCO. Pada proses matching/pencocokan didapatlah output klasifikasi sistem. Untuk hasil output yang tidak sama dengan target Dokter, maka hasil output salah dan hasil output yang sama dengan target Dokter, maka hasil output benar.

TABLE III

PERBANDINGAN TARGET FOLIKEL DAN OUTPUT SisTEM

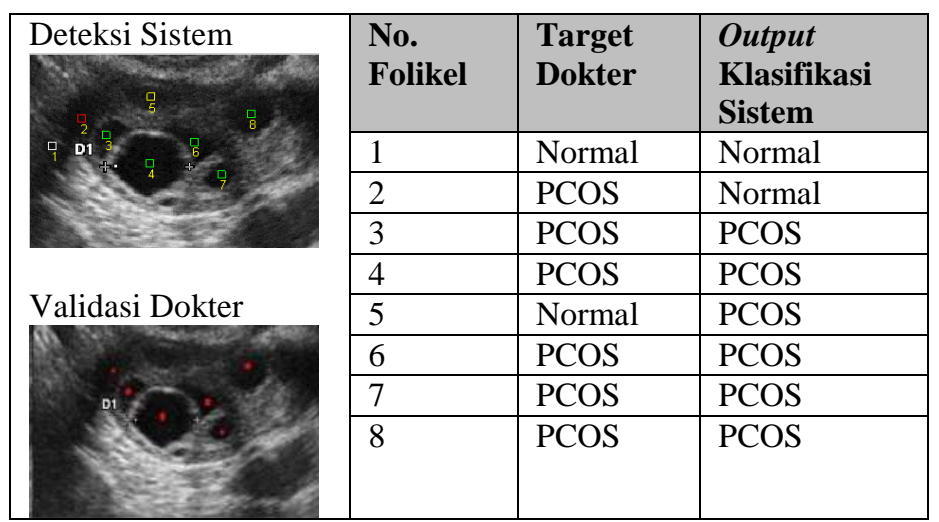

Data Training:

- Citra USG PCO: 11 image

- Citra USG Normal: 70 image

Berdasarkan data validasi Dokter terdapat 455 folikel PCO. Sedangkan, dari 81 citra tersebut, sistem mendeteksi 601 folikel yang berdasarkan target output dari validasi dokter dibagi menjadi dua kelas:

○ Folikel PCO: 310

- Folikel Non-PCO: 291

Sedangkan output dari sistem menghasilkan:

○ Folikel PCO: 339

- Folikel Non-PCO: 262

- Jumlah Benar: 454

- Jumlah Salah: 147

Dari hasil output 601 folikel yang dideteksi sistem pada proses training, akan dijadikan sebagai bank folikel, dimana folikel-folikel hasil deteksi pada proses testing akan dicocokkan dan diklasifikasikan dengan bank folikel yang telah disimpan pada proses training ini.

\section{B. Testing}

Berdasarkan kombinasi parameter terbaik dan model SVM yang didapatkan pada proses training, selanjutnya dilakukan klasifikasi folikel PCO dalam data testing berdasarkan model tersebut. Diawali dengan tahap preprocessing didapatkan folikel-folikel dari tiap image data testing. Diambil satu sample citra sebagai contoh gambaran proses.

a. Preprocessing

Pertama citra di-crop berdasarkan aturan yang sudah dianalisis ukurannya. Berikut gambar asli dari dokter, validasinya, dan hasil crop. 


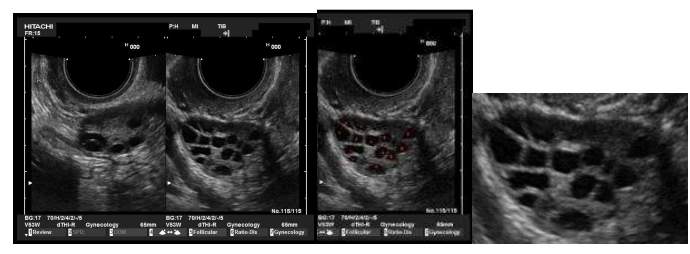

Gambar 17. Citra Asli, Validasi, dan Hasil Crop

Kemudian citra di preprocessing sehingga mendapat hasil deteksi folikel PCO dan dilakukan cropping.

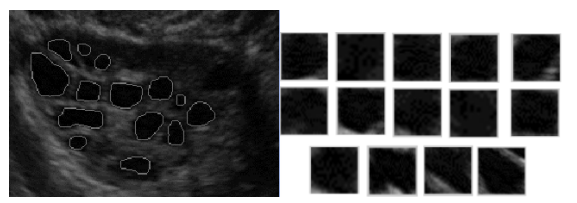

Gambar 18. Hasil Preprocessing

Hasil cropping dari semua citra akan dimasukkan dalam satu database folikel.

b. Ekstraksi Ciri

Folikel-folikel tersebut diekstraksi cirinya menggunakan Gabor Wavelet.

c. Target Dokter dan klasifikasi SVM

Tiap folikel diberikan target output sesuai validasi dari dokter. Kemudian dilakukan proses klasifikasi SVM yaitu mencocokkan cirinya dengan bank folikel training yang sudah diklasifikasikan pada kelas PCO dan non-PCO. Pada proses matching/pencocokan didapatlah output klasifikasi sistem. Untuk hasil output yang tidak sama dengan target Dokter, maka hasil output salah dan hasil output yang sama dengan target Dokter, maka hasil output benar.

TABLE IV

PERBANDINGAN TARGET Folikel DAN OUTPUT Sistem

\begin{tabular}{|c|c|c|c|}
\hline Deteksi Sistem & $\begin{array}{c}\text { No. } \\
\text { Folikel }\end{array}$ & $\begin{array}{l}\text { Target } \\
\text { Dokter }\end{array}$ & $\begin{array}{c}\text { Output } \\
\text { Klasifikasi } \\
\text { Sistem }\end{array}$ \\
\hline & 1 & $\mathrm{PCO}$ & $\mathrm{PCO}$ \\
\hline & 2 & $\mathrm{PCO}$ & $\mathrm{PCO}$ \\
\hline & 3 & $\mathrm{PCO}$ & $\mathrm{PCO}$ \\
\hline \multirow{11}{*}{ 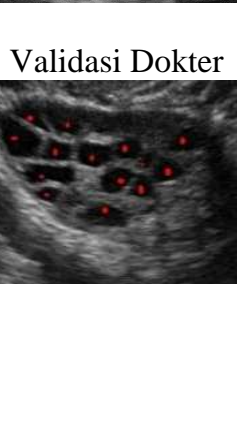 } & 4 & $\mathrm{PCO}$ & $\mathrm{PCO}$ \\
\hline & 5 & $\mathrm{PCO}$ & $\mathrm{PCO}$ \\
\hline & 6 & $\mathrm{PCO}$ & Normal \\
\hline & 7 & $\mathrm{PCO}$ & PCO \\
\hline & 8 & $\mathrm{PCO}$ & $\mathrm{PCO}$ \\
\hline & 9 & PCO & $\mathrm{PCO}$ \\
\hline & 10 & $\mathrm{PCO}$ & $\mathrm{PCO}$ \\
\hline & 11 & $\mathrm{PCO}$ & $\mathrm{PCO}$ \\
\hline & 12 & $\mathrm{PCO}$ & $\mathrm{PCO}$ \\
\hline & 13 & $\mathrm{PCO}$ & Normal \\
\hline & 14 & $\mathrm{PCO}$ & $\mathrm{PCO}$ \\
\hline
\end{tabular}

Data Testing:

- Citra USG PCO: 6 image

- Citra USG Normal: 34 image 
UNTARI NOVIA WiSESTY ET.AL.

Implementasi Gabor WaVElet dan Support Vector...

Berdasarkan data validasi Dokter terdapat 234 folikel PCO. Sedangkan, dari 40 citra tersebut, sistem mendeteksi 339 folikel yang berdasarkan target output dari validasi dokter dibagi menjadi dua kelas:

- Folikel PCO: 180

○ Folikel Non-PCO: 159

Sedangkan output dari sistem setelah di-matching-kan dengan bank folikel training menghasilkan:

○ Folikel PCO: 187

- Folikel Non-PCO: 152

○ Jumlah Benar: 266

- Jumlah Salah: 73

Maka dari hasil output dibandingkan dengan target validasi dokter didapat akurasi sebesar 78.466\%, True Positive Rate (Sensitivity) sebesar 81.77\%, dan True Negative Rate (Specificity) sebesar 74.68\%. Berdasarkan hasil performansi yang didapatkan tersebut, dapat disimpulkan bahwa system yang dibangun lebih sensitif terhadap deteksi penderita PCOS.

\section{KESIMPULAN}

Sistem yang mengkombinasikan Gabor Wavelet dan Support Vector Machine dapat diimplementasikan dalam mendeteksi folikel PCO. Berdasarkan data validasi Dokter yang berjumlah 234 folikel PCO pada data uji, sistem mampu mendeteksi 187 folikel PCO dan 152 folikel non-PCO. Setelah dibandingkan dengan target validasi dokter, jumlah folikel yang benar sesuai target validasi sebanyak 266 folikel. Sehingga didapat akurasi sebesar 78,466\%, Sensitivity sebesar $81.77 \%$, dan Specificity sebesar 74.68\%. Akurasi terbaik sistem pendeteksi PCO ini dicapai sebesar 75,541\% untuk data latih dan 78,466\% untuk data uji yaitu menggunakan ekstraksi ciri Gabor Wavelet 24 ciri pada parameter mask 17x17, frekuensi 2, 3, 4, $5 \mathrm{~Hz}$, sudut orientasi [ $\pi / 6 ; \pi / 6 ; \pi]$ dengan kombinasi SVM pada parameter $\mathrm{C}=160$, jenis kernel Polynomial tanpa menggunakan ciri Mean, Variance, Entropy, Kurtosis, dan Skewness.

Berdasarkan pengujian yang telah dilakukan, dapat disimpulkan bahwa system tersebut lebih sensitif dalam mendeteksi penderita PCOS dengan tingkat sensitivity $81.77 \%$. Untuk pengembangan system selanjutnya, diperlukan metode preprocessing, klasifikasi, validasi, dan dataset yang lebih memadai untuk meningkatkan performansi system.

\section{REFERENSI}

[1] Adiwijaya, PN Faoziyah, FP Permana, TAB Wirayuda, UN Wisesty, Tamper detection and recovery of medical image watermarking using modified LSB and Huffman compression, Second International Conference on Informatics and Applications (ICIA) 2013 pp.129 - 132. DOI:10.1109/ICoIA.2013.6650242.

[2] Adiwijaya, B. Purnama, U.N. Wisesty, A. Hasyim, Maulida, W. Astuti, Follicle Detection on the USG Images to Support Determination Polycystic Ovary Syndrome, Journal of Physics: Conference Series 622 (2015) 012027, DOI: 1088/1742$\underline{6596 / 622 / 1 / 012027}$

[3] Isnanto, R. Rizal, Identifikasi Iris Mata Menggunakan Tapis Gabor Wavelet Dan Jaringan Syaraf Tiruan Learning Vector Quantization (LVQ), Universitas Diponegoro, Semarang,2009.

[4] Nooshin Nabizadeh1, Miroslav Kubat2, Nigel John3, Clinton Wright4, Efficacy of Gabor-Wavelet versus Statistical Features for Brain Tumor Classification in MRI: A Comparative Study, Electrical and Computer Engineering Department, University Of Miami.

[5] P. Yang, S. Shan, W. Gao, S. Z. Li, D. Zhang, Face Recognition Using Ada-Boosted Gabor Features, The 6th IEEE International Conference On Automatic Face And Gesture Recognition (Fg2004), Seoul, Korea.

[6] Paulus, Klasifikasi Golongan Darah Menggunakan Gabor Wavelet Dan Support Vector Machine (SVM), Bandung, 2009.

[7] Nugroho, Anto Satriyo, dkk, Support Vector Machine-Teori dan Aplikasinya dalam bioinformatika.

[8] Trimiarsih, Zulfah Aprilianti, "Klasifikasi Kanker Usus berdasarkan Citra Mikroskopik Patologi Menggunakan Contourlet Transform dan Support Vector Machine (SVM)”, Institut Teknologi Bandung, Bandung, 2013.

[9] Adiwijaya, Aplikasi Matriks dan Ruang Vektor, Graha Ilmu, 2014.

[10] C. J. Liuand H.Wechsler, Gabor feature based classification using the enhanced fisher linear discriminant model for face recognition, IEEE Trans.Image Process., 11:467-476, 2002.

[11] Setiawati, E., Adiwijaya, Tjokorda, A.B.W., Particle Swarm Optimization on follicles segmentation to support PCOS detection, International Conference on Information and Communication Technology (ICoICT) 2015, DOI: $10.1109 /$ ICoICT.2015.7231453

[12] Littlewort-Ford, Gwen, Detecting Genuine Smiles With Support Vector Machines and Gabor Wavelets, Institute for Neural Computation, UCSD. 
[13] Lukas, Prisilia, Perancangan Aplikasi Sistem Pengenalan Iris Mata Menggunakan Metode Gabor Wavelet Pada Ekstraksi Ciri, Medan, 2013.

[14] M. J. Lyons, Julien Budynek, Andre Plantey, Shigeru Akamatsu, Classifying Facial Attributes Using A 2-D Gabor Wavelet Representation And Discriminant Analysis, The 4th IEEE International Conference On Automatic Face And Gesture Recognition (Fg 2000), 26-30 March 2000, Grenoble, France.

[15] Purnama, Bedy, Wisesty, Untari N., Adiwijaya, Nhita, F., Gayatri, A., Mutiah, T., A classification of polycystic Ovary Syndrome based on follicle detection of ultrasound images, Information International Conference on Information and Communication Technology (ICoICT) 2015, DOI:10.1109/ICoICT.2015.7231458

[16] Ashika, 2013, Ovarian Follicle Detection for Polycystic Ovary Syndrome using Fuzzy C-Means Clustering, International Journal of Computer Trends and Technology (IJCTT) volume 4 Issue 7.

[17] Akkasaligar, Prema T. and Malagavi Girijamma V. 2014. Detection of Cysts in Medical Ultrasound Images of Ovary. In Proc. SARC-IRF 5^ International Conference Bangalore, India. ISBN 978-93-84209-13-1. 
